\title{
Capitalizing on Economic Function of the Institution of Zakāt in Modern Economy
}

\author{
Salman Ahmed Shaikh \\ SZABIST Karachi, Pakistan
}

\begin{abstract}
This study analyzes the economic potential of the institution of Zakāt on income redistribution, poverty and aggregate demand. Through a mathematical exposition, we show that if a person keeps idle investible wealth, then Zakāt will deplete the idle wealth over time. On the macroeconomic front, proportional Zakät linked with income will act as an automatic stabilizer. If an economy is in disequilibrium and policies fail to immediately recover and boost incomes, wealth Zakat will enable the distributive allocation that works independently of the business cycles and will help in stabilizing the extremes of the business cycles. In this way, wealth Zakāt will act as a permanent stabilizer. We discuss that Zakāt is an important tool for redistributing income and it can also increase aggregate spending. The redistribution from people with lower MPC to people with higher MPC will boost aggregate spending even with the same level of aggregate income. Finally, we recommend certain steps at the policy and implementation level so that the institution of Zakät can be effectively utilized to contribute in poverty alleviation. We recommend that it is appropriate to disburse Zakāt at the federal level. This way, the regional disparities can be reduced more effectively. To gain the trust and the confidence of people, it is vital to improve the governance and transparency. In this regard, we recommend that the Zakät collection and disbursement details shall be reported in a standard way periodically. We also highlight the importance of creating synergies between Zakät and other welfare programs. We also draw attention towards modifying the accounting standards to achieve transparent computation, assessment and collection.
\end{abstract}

\section{INTRODUCTION TO ZAKĀT}

Zakāt is an important institution in an Islamic economic framework for poverty alleviation and economic welfare. In Islam, Zakāt is a religious obligation to pay a part of wealth and production to the government (Chapter Tauba: Verse 103). As per Islamic injunctions, the government has to spend the Zakät funds on specified heads for public welfare (Chapter Tauba: Verse 60).

In its economic character, Zakāt is a combination of a net worth levy and a production levy. The institution of Zakāt comprises a net worth tax of $2.5 \%$ on all bases of wealth except for the wealth below Nisāb and the assets in regular personal use like home, personal transport and furniture (Haneef \& Mahmud, 2011). According to the mainstream Islamic jurisprudence, wealth subject to Zakāt would include:

- Metals identified in Hadith (Gold \& Silver) and used as currency.

* Livestock.

* Tradable inventory.

* Currency note and coins (legal tender).

* Financial securities convertible in currency

o Investment in stocks.

- Investment in bonds.

o Investment and money held in bank deposits.

- Investments in mutual funds etc. 
The derivation for production tax comes from the fact that the produce from rain-fed lands was subject to a $10 \%$ production value tax whereas, the produce from irrigated lands (which had to be provided with capital in the form of water supply) was subject to a $5 \%$ production value tax in the Prophet's (PBUH) time.

If we look at the institution of Zakāt, we find that the payer of Zakāt and the receiver of Zakāt belong to two different income classes. The payer of Zakāt is non-poor with surplus wealth above Nisāb. On the other hand, the receiver of Zakät is usually a poor person with no surplus wealth above Nisāb. Thus, the threshold wealth of Nisāb makes a distinction between the payer and receiver and helps to achieve targeted income and wealth transfer to the people who are usually the poor people. Since this redistribution is based on wealth rather than income, it can achieve the redistribution objectives more effectively and consistently since wealth fluctuates much less than income over the business cycles.

Oxfam (2017) reports that 8 individual persons have as much wealth as bottom $50 \%$ of the entire global population. Their combined wealth is $\$ 426.2$ billion as of end-2016. As per World Bank, there are 767 million people below the poverty line of $\$ 1.90 /$ day. It means that poverty gap is $\$ 531.9$ billion $(1.90 \times 767,000,000 \times 365)$ per year. Comparing the wealth owned by only the richest 8 persons ( $\$ 426.2$ billion) and the total global poverty gap funding requirement ( $\$ 531.9$ billion), one can see how redistribution of wealth can help in pooling poverty alleviation funds. Oxfam (2017) reports that global wealth has reached \$255 trillion. It is enough to give $\$ 1$ a day to 767 million poor people for 910 years. A single year $2.5 \%$ Zakāt on it will give $\$ 1$ a day to 767 million poor for 23 years.

According to the Food and
Agricultural Organization (FAO), there are approximately 800 million people who suffer from hunger and are food insecure in their routine lives. Most of the poor countries lack basic resources to kick-start growth and to invest in health and education. Thus, the redistribution of resources is vital to enhance income as well as the capacity to earn sustainable incomes, which requires income support programs, basic health and education as well as microfinance to build small enterprises.

According to The Hunger Project, 2.4 billion people do not have adequate sanitation and each day, nearly 1,000 children die due to preventable water and sanitation-related diarrheal diseases. It is partly because sanitation is not good business as compared to cellular services and life's other comforts and luxuries. Interestingly, according to the Food and Agricultural Organization (2013), for the world as a whole, per capita food supply rose from about 2,200 kcal a day in the early 1960 s to more than $2,800 \mathrm{kcal}$ a day by 2009 . The institution of Zakāt could help in providing income support to poor people who are food insecure due to lower and unsustainable incomes.

Nearly 50 percent of the people living in extreme poverty are 18 years old or younger. This goes on to show that a significant portion of our global population would not have a fair start to achieve socio-economic mobility. Thus, proper nourishment, basic medicines and vaccinations are necessary to avoid illhealth, stunting and loss of capacities for independent productive living in adulthood. Some life-saving medicines cost less than a dollar, but they are underprovided due to commercial reasons. Unless effective redistribution happens, the purchasing power cannot be enhanced which is vital to afford even the basic necessities today, such as food, water and medicines.

Providing quality education is vital for achieving permanent poverty 
exit, enhancement of skills and capacities, and to ensure upward social mobility. The financial institutions can come to the rescue once the people are able to hold enough assets and skills for the commercial entrepreneurship. But, much before that, people require survival and human capital development in the early stage of life.

Paul Romer, winner of 2018 Nobel Laureate in Economics worked on scarcity of positive externalities ideas. His policy suggestion was that there should be subsidies given and patents approved to engender ideas. But, weakly funded and indebted governments face problems in affording subsidies. Patents might provide incentives to the producers, but at the same time, it has resulted in under provision and overpricing of lifesaving medicines for concentrating large profits of commercial manufacturers. An alternate is to address the ethical concern via culture and values. Quran (5:2) says: "Help you one another in good deeds and righteousness, but do not help one another in sin and transgression." Decentralized provision of public goods and services through Zakāt and Waqf can enhance the social safety net. There are mosque-based schools in the Muslim majority countries which effectively channelize Zakāt funds to ensure basic religious and secular education. Effective administration and management of the Zakāt funds can help in scaling up the benefits in terms of strengthening institutions to create synergistic effects.

Decent work and economic growth are necessary to realize a sustainable reduction in poverty and in ensuring upward socio-economic mobility. On one hand, Zakāt from endowment surplus households (those having higher wealth than Nisāb) to the endowment deficient households can help in providing income support and affordability for skills enhancement programs. Zakāt could also be used to provide funding for education and health institutions, thereby contributing to human capital development which can provide decent work. On the other hand, the institution of Zakāt would ensure circulation of wealth in the productive enterprise, thereby directing capital to go in the real sector of the economy rather than sitting idle in the hands of the wealthy individuals.

\section{LITERATURE REVIEW}

Wahid (1986) explains that Zakāt is a compulsory payment on the part of Muslims as a share to the poor, having a wide variety of economic and social ramifications. In the early empirical literature on welfare potential of Infaq (charity) to alleviate poverty in Pakistan, Malik et al (1994) use micro data to establish that Infaq (charity) does have a significant impact on reducing poverty gap. In a recent empirical study for OIC countries, Shirazi \& Amin (2009) estimate the resources required for poverty elimination under $\$ 1.25$ a day and \$2.0 a day respectively. Their estimates for Pakistan suggest that Pakistan needs $1 \%$ of GDP for poverty elimination under $\$ 1.25$ a day and needs $6.77 \%$ of GDP for poverty elimination under \$2 a day. For Pakistan, Kahf (1989) uses different Zakāt categories and according to his estimate, Zakāt collection can be between $1.6 \%$ of GDP to $4.4 \%$ of GDP.

In a more recent study, Azam et al (2014) in an empirical study for Pakistan establish that Zakāt significantly enhances the welfare of the households. M. Akram \& Afzal (2014) in an empirical study for Pakistan argue that Zakāt disbursement among the poor, needy, destitute, orphans and widows has played a significant role in poverty alleviation. Their results show that there is an inverse relationship between poverty and Zakāt disbursement both in the short run and in the long run. 
Using aggregate data for Malaysia, Suprayitno et al (2013) find that Zakāt distribution has a positive, but small impact on aggregate consumption. Hence, Zakāt distribution should not be limited to the consumption needs, but should also cover other forms of monetary aid that can generate a continuous flow of income for Zakāt recipients. In another recent study, Abdelmawla (2014) argue based on empirical evidence using aggregated data for Sudan that Zakāt along with educational attainment significantly reduced poverty in Sudan.

In another empirical study for Bangladesh, Hassan and Jauanyed (2007) estimate that Zakāt funds can replace the government budgetary expenditures ranging from $21 \%$ of Annual Development Plan (ADP) in 1983-84 to $43 \%$ of ADP in 2004-2005. For Malaysia, Sadeq (1996) finds that about $73 \%$ of the estimated potential Zakāt collection will be needed annually to change the status of hard-core households to a status of non-poor households in Malaysia. Ibrahim (2006) contends in an empirical study for Malaysia that Zakāt distribution reduces income inequality. His analysis reveals that Zakāt distribution reduces poverty incidence, reduces the extent of poverty and lessens the severity of poverty. Firdaus et al (2012) estimate the potential of Zakāt in Indonesia by surveying 345 households. Their results show that Zakāt collection could reach $3.4 \%$ of Indonesia's GDP.

Some studies also show the comparative potential of Zakāt as a superior tool for poverty alleviation. Debnath et al (2013) assess the effectiveness of Zakât as an alternative to microcredit in alleviating poverty in Bangladesh. Through the Propensity Score Matching (PSM) techniques, the study reveals that the impact of Zakāt scheme has proven to be greater than the microcredit programs. Besides that, the study also highlights that Zakāt scheme significantly increases both income and expenditure of the recipients in comparison to the microcredit programs.

Some studies like Nadzri et al (2012) recommend integrating the various poverty alleviation and redistribution tools for creating synergies. The effectiveness of Zakāt institutions may improve by collaborating with other institutions such as Microfinance institutions. Shirazi (2014) suggests that the institutions of Zakāt and Waqf need to be integrated into the poverty reduction strategy of the Islamic Development Bank (IDB) member countries. The proceeds of these institutions should be made as part of their pro-poor budgetary expenditures. Hassan (2010) suggests a model which combines Islamic Microfinance with two traditional Islamic tools of poverty alleviation such as Zakāt and Waqf in an institutional setup. Hassan (2010) argues that the poor borrowers will have less debt burden as their capital investments will be partly met by funds from Zakāt that does not require any repayment.

Norazlina and Rahim (2011) identify that there are many types of programs that could be funded by Zakāt such as providing education for the poor, the establishment of schools, vocational training and rehabilitation for Zakāt recipients to make them more productive, establishment of agriculture and cottage industries, provision of fixed asset and equipment to small business projects, provision of working capital, building of low-cost housing and providing medical treatment and health care.

To achieve such diverse contemporary needs, the institution of Zakāt is very dynamic and flexible. In Umer (rta) and Abu Bakar (rta) period of government, Zakāt was collected by the government. But, in Usman (rta) period, people were allowed to pay Zakāt privately (Kuran, 2003). Horses were exempted from Zakāt in the Prophet's time, but, Umer (rta) brought them in the 
Zakāt net in His period. Similarly, Mahmud (2001) argues that the institution of Zakāt is flexible to a certain degree as Umer (rta) levied Zakāt on horses and skins and at the time when Arab was hit with a drought and famine, he exempted poor from Zakāt and suspended Zakāt from the rich. Usman (rta) also levied Zakāt on the production in forests which was not the case in the earlier period (Nadvi, 1996). Hence, a policy maker in a modern economy can use this institution flexibly to maximize the welfare benefits of the Zakāt system.

Nevertheless, Zakāt is not collected by the government nowadays in most countries and is not considered a compulsory payment to the government (Powell, 2009). Ahmad et al. (2006) examine factors contributing to the dissatisfaction towards formal Zakāt institutions based on a sample of 753 respondents who paid Zakāt to six privatized institutions. Their study uses logistic regression to analyse the probability of paying to such Zakāt institutions. Their results indicate that the satisfaction on the distribution and efficient management of Zakät are the main factors influencing Zakāt payment. About $57 \%$ of the respondents were dissatisfied with the distribution of Zakāt funds which significantly affects payments to the Zakât institutions. Wahid et al. (2008) reveal two main factors contributing to dissatisfaction, i.e. the ineffectiveness of Zakāt distribution and the lack of transparency on information about the distribution of Zakât. The lack of confidence in the governance of Zakāt institutions due to the perceived lack of efficiency and effectiveness may directly undermine the Zakāt institutions in attaining their desired socio- economic objectives.

Abu Bakar et al (2007) argue that there may be a lack of proper implementation of Zakāt in Muslim majority countries which limits the success of the noble aims of Zakāt.
Abdullah and Suhaib (2011) argue that if Zakāt is established as an institution, it will create a collective social security scheme for mutual help and the resources can be further utilized for social development.

Yusoff (2011) urges that every Muslim country must organize Zakāt collection and Zakāt spending in the most effective and efficient manner. Azam et al (2014) also suggest that there is a need to institutionalize the Zakāt collection system to increase the overall Zakāt collection. Rahman (2003) proposes the introduction of two Zakät governance measures, i.e. the promulgation of Islamic accounting standard, and structural and policy reform towards more effective Zakāt distribution.

Besides governance, there is a dire need for a standardized approach on Zakāt base. Shirazi and Amin (2009) argue that since there is no agreement among the scholars on the new wealth that may be brought under the Zakāt net, there is an urgent need for the general agreement on the definition of the items, which may be taken as Zakätable items. This requires Ijma (consensus) of the ulama (Islamic scholars) and other contemporary scholars on the issue.

On the need for extending the Zakāt net by including all forms of wealth and produce, Qardawi (1999, p. 333) applies the methodology of Qiyas (analogical reasoning) and reasons that the emerging and increasing types of wealth in modern times such as bank deposits and financial securities like shares and bonds are also Zakātable (Qaradawi, 1999). Abu Bakar et al (2007) also suggest that the illah (basis or reasoning) for Zakâtability should no longer be productive property, but any property which is in excess of one's personal use. Haneef and Mahmud (2011) also argue that the general directives of the Quran do not restrict the application of Zakāt to certain types of wealth to the exclusion of others. 
That is why; wealth or assets subject to Zakāt should include cash in hand or at the bank, gold and silver, heldfor trade inventory, real estate purchased for the purpose of resale and all types of financial investments in stocks, bonds, debentures, national saving schemes and mutual funds.

Likewise, production is not limited to agriculture nowadays. The major part of production comes from industries as well as services sector. Therefore, income from industrial production could also be taxed just like agriculture. Income from services sector could also be taxed on the same principle.

Next, we discuss another issue that whether the investment in financial instruments shall be subject to wealth Zakāt on total investment value or only the income from such financial investments shall be subject to income Zakāt. Khan (2005) contends that investment in stocks should be interpreted as any other investment with some means of earning income. Investment in a stock is a means of earning dividend income or capital gains. Just like means of production/income are exempted from Zakāt, investment in stocks should be exempted from wealth Zakāt as per that view. Therefore, any income arising from investment in stocks must be subject to income Zakāt. Similarly, this argument could be extended to introduce income Zakät on mutual funds, investment in National Savings Schemes (NSS), debentures, bonds and related instruments. Furthermore, if a real estate is leased, the real estate becomes the means of earning rent for the owner. Hence, income Zakāt could also be introduced on rental income.
However, if employees or directors are given bonuses in the form of stock ownership, they will have to pay $5 \%$ Zakāt on income from investment in stocks. It is due to the fact that in this case, the participation in the business venture is not only by way of providing capital, but also by providing labor. One crucial advantage from this policy is that the directors will be willing to make the company grow and own its stock so as to benefit not only from the dividend/capital gains, but also to be able to pay less tax on that income i.e. $5 \%$ rather than $10 \%$. This will also mitigate the agency problem as well in an effective way.

To summarize, we see that on theoretical grounds, Zakāt is an important economic institution. If the governments improve the governance, administration and effective and transparent use of Zakāt funds, then tremendous gains can be achieved in improving public welfare.

\section{Economic Effects of Islamic Redistribution Institutions}

In this section, we show how the institution of Zakāt impacts macroeconomic aggregates in an interestfree economy. We also want to highlight the impact of Zakāt on the wealth redistribution.

\section{Effects of Zakät on Wealth Redistribution}

In this section, we present a simple illustration of how the institution of Zakāt in an Islamic economy reduces wealth concentration. For a particular individual, net Zakät wealth at a point in time is given by equation (1):

$$
\mathrm{W}_{\mathrm{t}}=\mathrm{Y}_{\mathrm{t}}-0.025\left(\mathrm{NZW}_{\mathrm{t}-1}\right)+\mathrm{W}_{\mathrm{t}-1}-\mathrm{C}_{\mathrm{t}}--(1)
$$

Here,

$Y_{t}$ is income of an individual in time period ' $t$ '.

$\mathrm{NZW}_{\mathrm{t}-1}$ is the base of wealth that will be used for Zakāt deduction. 
$\mathrm{W}_{\mathrm{t}-1}$ is the wealth of individual ' $\mathrm{i}$ ' in the previous time period.

$\mathrm{C}_{\mathrm{t}}$ is the consumption in time period ' $\mathrm{t}$ '.

Simplifying equation (1), we get:

$\mathrm{W}_{\mathrm{t}}=\mathrm{Y}_{\mathrm{t}}-0.025\left(\mathrm{~W}_{\mathrm{t}-1}-\mathrm{N}_{\mathrm{t}-1}\right)+\mathrm{W}_{\mathrm{t}-1}-\mathrm{C}_{\mathrm{t}}$

$\mathrm{W}_{\mathrm{t}}=\mathrm{Y}_{\mathrm{t}}-0.025 \mathrm{~W}_{\mathrm{t}-1}+\mathrm{W}_{\mathrm{t}-1}+0.025 \mathrm{~N}_{\mathrm{t}-1}-\mathrm{C}_{\mathrm{t}} \mathrm{W}_{\mathrm{t}}=\mathrm{Y}_{\mathrm{t}}+0.975 \mathrm{~W}_{\mathrm{t}-1}+0.025 \mathrm{~N}_{\mathrm{t}-1}-$ $\mathrm{C}_{\mathrm{t}}$

Expanding it iteratively forward, we get

$$
\begin{aligned}
& \mathrm{W}_{\mathrm{t}+1}=\mathrm{Y}_{\mathrm{t}+1}+\mathrm{W}_{\mathrm{t}}-0.025\left(\mathrm{~W}_{\mathrm{t}}-\mathrm{N}_{\mathrm{t}}\right)-\mathrm{C}_{\mathrm{t}+1} \mathrm{~W}_{\mathrm{t}+1}=\mathrm{Y}_{\mathrm{t}+1}+0.975 \mathrm{~W}_{\mathrm{t}}+0.025 \mathrm{~N}_{\mathrm{t}}-\mathrm{C}_{\mathrm{t}+1} \\
& \mathrm{~W}_{\mathrm{t}+1}=\mathrm{Y}_{\mathrm{t}+1}+0.975\left(\mathrm{Y}_{\mathrm{t}}+0.975 \mathrm{~W}_{\mathrm{t}-1}+0.025 \mathrm{~N}_{\mathrm{t}-1}-\mathrm{C}_{\mathrm{t}}\right)+0.025 \mathrm{~N}_{\mathrm{t}}-\mathrm{C}_{\mathrm{t}+1} \\
& \mathrm{~W}_{\mathrm{t}+1}=\mathrm{Y}_{\mathrm{t}+1}+0.975 \mathrm{I}_{\mathrm{t}}+0.950625 \mathrm{~W}_{\mathrm{t}-1}+0.024375 \mathrm{~N}_{\mathrm{t}-1}+0.025 \mathrm{~N}_{\mathrm{t}}-0.975 \mathrm{C}_{\mathrm{t}}- \\
& \mathrm{C}_{\mathrm{t}+1^{--}}(2)
\end{aligned}
$$

It can be seen that the wealth function will deplete base year wealth as time moves on and the overall wealth can only increase with the increase in labor income and legitimate sources of non- labor income in an interest free economy. In Table 1, we give a numerical example of wealth redistribution under the Zakāt system.

Table 1. Simulation of Wealth Redistribution under the Zakāt System

\begin{tabular}{|c|c|c|c|c|c|}
\hline Year & $\mathbf{W}_{\mathbf{R}}$ & $\begin{array}{c}\text { Wealth Transfer } \mathbf{R} \\
\text { to P) }\end{array}$ & $\mathbf{W}_{\mathbf{P}}$ & $\begin{array}{c}\mathbf{W}_{\mathbf{R}} \text { to } \mathbf{W}_{\mathbf{P}} \\
\text { Multiple }\end{array}$ & $\begin{array}{c}\mathbf{W}_{\mathbf{R}} \text { to } \mathbf{W}_{\mathbf{P}} \\
\text { Multiple Per } \\
\text { Person }\end{array}$ \\
\hline 0 & $10,100.00$ & & 100.00 & 101.00 & 505.00 \\
\hline 1 & $9,850.00$ & 250.00 & 350.00 & 28.14 & 140.71 \\
\hline 2 & $9,606.25$ & 243.75 & 593.75 & 16.18 & 80.89 \\
\hline 3 & $9,368.59$ & 237.66 & 831.41 & 11.27 & 56.34 \\
\hline 4 & $9,136.88$ & 231.71 & $1,063.12$ & 8.59 & 42.97 \\
\hline 5 & $8,910.96$ & 225.92 & $1,289.04$ & 6.91 & 34.56 \\
\hline 6 & $8,690.68$ & 220.27 & $1,509.32$ & 5.76 & 28.79 \\
\hline 7 & $8,475.92$ & 214.77 & $1,724.08$ & 4.92 & 24.58 \\
\hline 8 & $8,266.52$ & 209.40 & $1,933.48$ & 4.28 & 21.38 \\
\hline 9 & $8,062.36$ & 204.16 & $2,137.64$ & 3.77 & 18.86 \\
\hline 10 & $7,863.30$ & 199.06 & $2,336.70$ & 3.37 & 16.83 \\
\hline 11 & $7,669.21$ & 194.08 & $2,530.79$ & 3.03 & 15.15 \\
\hline 12 & $7,479.98$ & 189.23 & $2,720.02$ & 2.75 & 13.75 \\
\hline 13 & $7,295.48$ & 184.50 & $2,904.52$ & 2.51 & 12.56 \\
\hline 14 & $7,115.60$ & 179.89 & $3,084.40$ & 2.31 & 11.53 \\
\hline 15 & $6,940.21$ & 175.39 & $3,259.79$ & 2.13 & 10.65 \\
\hline 16 & $6,769.20$ & 171.01 & $3,430.80$ & 1.97 & 9.87 \\
\hline 17 & $6,602.47$ & 166.73 & $3,597.53$ & 1.84 & 9.18 \\
\hline
\end{tabular}




\begin{tabular}{|l|l|l|l|l|l|}
\hline 18 & $6,439.91$ & 162.56 & $3,760.09$ & 1.71 & 8.56 \\
\hline 19 & $6,281.41$ & 158.50 & $3,918.59$ & 1.60 & 8.01 \\
\hline 20 & $6,126.88$ & 154.54 & $4,073.12$ & 1.50 & 7.52 \\
\hline 21 & $5,976.20$ & 150.67 & $4,223.80$ & 1.41 & 7.07 \\
\hline 22 & $5,829.30$ & 146.91 & $4,370.70$ & 1.33 & 6.67 \\
\hline 23 & $5,686.07$ & 143.23 & $4,513.93$ & 1.26 & 6.30 \\
\hline 24 & $5,546.42$ & 139.65 & $4,653.58$ & 1.19 & 5.96 \\
\hline 25 & $5,410.26$ & 136.16 & $4,789.74$ & 1.13 & 5.65 \\
\hline 26 & $5,277.50$ & 132.76 & $4,922.50$ & 1.07 & 5.36 \\
\hline 27 & $5,148.06$ & 129.44 & $5,051.94$ & 1.02 & 5.10 \\
\hline
\end{tabular}

Source: Author's Computations

Suppose we have an interest free economy that comprises 10 rich people each having wealth of RM 10,100. We also assume that there are 50 poor people each having wealth of RM 100. Let us suppose that the Nisāb amount in this interest free economy is RM 10 per person. Column 2 shows the aggregate wealth of rich people. Column 3 shows the wealth transferred from the rich to the poor each year. Column 4 shows the aggregate wealth of poor people after wealth transfer. For simplicity, we suppose perfect wealth equality between the people in each of the group. For the sake of highlighting the effect of wealth redistribution of wealth transfers, we assume that income is generated randomly in this interest free economy with no interest based lending allowed. Furthermore, we assume that income earned is consumed in that period to enable us to focus our attention on the wealth redistribution effect of Zakāt in an interest free economy. Column 5 shows the wealth multiple in each year for the two groups. It can be seen that after around 27 years, the wealth multiple will drastically go down from 101 to almost 1 for the two groups as a whole. Column 6 shows the wealth multiple per person. It can be seen that wealth multiple will become only 5 after 27 years from the initial value of 505. Eventually, the wealth recipients will become ineligible for Zakāt receipts and rather will become part of the Zakāt payer group.

Table 2 presents a similar analysis with the assumption that there is a uniform 5\% growth in endowments that rich and poor people experience. It can be seen that this growth does not affect wealth distribution. The redistribution is impactful both without and also with growth. Thus, redistribution is not dependent on business cycle or growth. Even if growth happens, it is egalitarian in this interest free economy in the presence of the institution of Zakāt.

Another interesting aspect is the boost in aggregate demand which is given in the last column of Table 2. The marginal increase in surplus wealth would mostly be saved by the rich. Since this wealth is transferred to the poor with little endowments, it is likely to be consumed. Thus, assuming a marginal propensity to consume value of 0.9 , the last column of Table 2 presents the additional increase in aggregate demand which will happen every year in the interest free economy with a uniform growth rate of $5 \%$ and in the presence of the institution of Zakāt. This boost in aggregate demand would support the business cycle against economic slumps. Finally, this boost in aggregate demand is not a function of loose monetary or expansionary fiscal policy. Thus, it will not create the problem of inflation or 
crowding out in the economy.

Table 2. Simulation of Wealth Redistribution under the Zakāt System with Growth

\begin{tabular}{|c|c|c|c|c|c|c|}
\hline Year & $\mathbf{W}_{\mathrm{R}}$ & $\begin{array}{c}\text { Wealth } \\
\text { Transfer (R to } \\
\text { P) }\end{array}$ & $\mathbf{W}_{\mathbf{P}}$ & $\begin{array}{l}W_{R} \text { to } W_{P} \\
\text { Multiple }\end{array}$ & $\begin{array}{c}\mathbf{W}_{\mathbf{R}} \text { to } \mathrm{W}_{\mathbf{P}} \\
\text { Multiple Per } \\
\text { Person }\end{array}$ & $\begin{array}{c}\text { Boost in } \\
\text { AD }\end{array}$ \\
\hline 0 & $10,100.00$ & & 100.00 & 101.00 & 505.00 & \\
\hline 1 & $10,339.88$ & 252.50 & 357.50 & 28.92 & 144.61 & 227.25 \\
\hline 2 & $10,585.45$ & 258.50 & 633.87 & 16.70 & 83.50 & 232.65 \\
\hline 3 & $10,836.85$ & 264.64 & 930.20 & 11.65 & 58.25 & 238.17 \\
\hline 4 & $11,094.23$ & 270.92 & $1,247.63$ & 8.89 & 44.46 & 243.83 \\
\hline 5 & $11,357.71$ & 277.36 & $1,587.37$ & 7.16 & 35.78 & 249.62 \\
\hline 6 & $11,627.46$ & 283.94 & $1,950.68$ & 5.96 & 29.80 & 255.55 \\
\hline 7 & $11,903.61$ & 290.69 & $2,338.90$ & 5.09 & 25.45 & 261.62 \\
\hline 8 & $12,186.32$ & 297.59 & $2,753.44$ & 4.43 & 22.13 & 267.83 \\
\hline 9 & $12,475.75$ & 304.66 & $3,195.77$ & 3.90 & 19.52 & 274.19 \\
\hline 10 & $12,772.05$ & 311.89 & $3,667.45$ & 3.48 & 17.41 & 280.70 \\
\hline 11 & $13,075.38$ & 319.30 & $4,170.12$ & 3.14 & 15.68 & 287.37 \\
\hline 12 & $13,385.92$ & 326.88 & $4,705.51$ & 2.84 & 14.22 & 294.20 \\
\hline 13 & $13,703.84$ & 334.65 & $5,275.44$ & 2.60 & 12.99 & 301.18 \\
\hline 14 & $14,029.31$ & 342.60 & $5,881.81$ & 2.39 & 11.93 & 308.34 \\
\hline 15 & $14,362.50$ & 350.73 & $6,526.63$ & 2.20 & 11.00 & 315.66 \\
\hline 16 & $14,703.61$ & 359.06 & $7,212.02$ & 2.04 & 10.19 & 323.16 \\
\hline 17 & $15,052.82$ & 367.59 & $7,940.21$ & 1.90 & 9.48 & 330.83 \\
\hline 18 & $15,410.33$ & 376.32 & $8,713.55$ & 1.77 & 8.84 & 338.69 \\
\hline 19 & $15,776.32$ & 385.26 & $9,534.48$ & 1.65 & 8.27 & 346.73 \\
\hline 20 & $16,151.01$ & 394.41 & $10,405.61$ & 1.55 & 7.76 & 354.97 \\
\hline 21 & $16,534.60$ & 403.78 & $11,329.67$ & 1.46 & 7.30 & 363.40 \\
\hline 22 & $16,927.29$ & 413.36 & $12,309.52$ & 1.38 & 6.88 & 372.03 \\
\hline 23 & $17,329.32$ & 423.18 & $13,348.18$ & 1.30 & 6.49 & 380.86 \\
\hline 24 & $17,740.89$ & 433.23 & $14,448.82$ & 1.23 & 6.14 & 389.91 \\
\hline 25 & $18,162.23$ & 443.52 & $15,614.78$ & 1.16 & 5.82 & 399.17 \\
\hline 26 & $18,593.59$ & 454.06 & $16,849.57$ & 1.10 & 5.52 & 408.65 \\
\hline 27 & $19,035.18$ & 464.84 & $18,156.89$ & 1.05 & 5.24 & 418.36 \\
\hline
\end{tabular}

Source: Author's Computations

\section{Impact of Zakāt on Macroeconomic Outcomes}

Hartman (2002) cites the case of the US economy and argues that the progressive taxes were designed to reduce income inequality. But during the last four decades, while the share of income taxes levied on the upper tenth of incomes rose
$15 \%$, the after-tax income share of the remainder of incomes declined $13 \%$. He concludes that progressive taxation has failed to reduce the disparity of real incomes.

Mainstream economic theory and policy based on it has not been able to create an equitable balance between the capitalists and the labor class, especially 
in the presence of extractive institutions like interest based earnings on accumulated wealth and incapacitated wealth redistribution mechanisms. In Table 3, we present net ODA and official aid received in selected OIC countries. In terms of absolute figures, Afghanistan, Syria, Pakistan, Egypt and Turkey received the highest assistance in absolute numbers. However, when we look at the assistance received on per capita basis, we find that OIC countries with the greatest number of the poor population receive very low assistance on per capita basis.

Table 3. Net ODA and Official Aid in Selected OIC Countries

\begin{tabular}{|l|c|c|l|c|c|}
\hline \multicolumn{1}{|c|}{ Country } & $\begin{array}{c}\text { Net ODA + } \\
\text { Aid (mIn \$) }\end{array}$ & $\begin{array}{c}\text { ODA + Aid } \\
\text { Per Capita }\end{array}$ & \multicolumn{1}{|c|}{ Country } & $\begin{array}{c}\text { Net ODA + } \\
\text { Aid (mln \$) }\end{array}$ & $\begin{array}{c}\text { ODA + Aid } \\
\text { Per Capita }\end{array}$ \\
\hline Gaza & 2,481 & 560.98 & Niger & 914 & 45.96 \\
\hline Jordan & 2,677 & 352.43 & Guinea & 561 & 44.51 \\
\hline Kosovo & 576 & 319.53 & Turkey & 3,410 & 43.34 \\
\hline Syria & 4,330 & 234.04 & Yemen & 1,150 & 42.87 \\
\hline Guyana & 165 & 214.84 & Tajikistan & 356 & 41.99 \\
\hline Djibouti & 164 & 184.44 & Uganda & 1,622 & 41.56 \\
\hline Bosnia & 631 & 165.69 & Cote d'Ivoire & 917 & 40.41 \\
\hline Afghanistan & 4,801 & 147.60 & Egypt & 3,510 & 38.35 \\
\hline Lebanon & 816 & 139.46 & Iraq & 1,389 & 38.13 \\
\hline Sierra Leone & 882 & 136.68 & Cameroon & 842 & 36.09 \\
\hline Kyrgyz Rep. & 651 & 109.29 & Libya & 207 & 33.03 \\
\hline Somalia & 1,106 & 102.52 & Togo & 207 & 28.37 \\
\hline Albania & 280 & 96.94 & Chad & 386 & 27.53 \\
\hline Comoros & 74 & 93.55 & Suriname & 13 & 23.15 \\
\hline Tunisia & 930 & 82.68 & Sudan & 867 & 21.54 \\
\hline Mozambique & 2,096 & 74.92 & Pakistan & 3,584 & 18.97 \\
\hline Senegal & 1,104 & 72.98 & Bangladesh & 2,412 & 14.98 \\
\hline Mali & 1,233 & 70.05 & Nigeria & 2,437 & 13.37 \\
\hline Morocco & 2,228 & 64.81 & Uzbekistan & 324 & 10.36 \\
\hline Gabon & 111 & 64.27 & Turkmenistan & 35 & 6.44 \\
\hline Mauritania & 257 & 63.25 & Kazakhstan & 88 & 4.99 \\
\hline Maldives & 25 & 62.00 & Algeria & 156 & 3.92 \\
\hline Burkina Faso & 1,115 & 61.57 & Iran & 77 & 0.98 \\
\hline Guinea-Bissau & 109 & 58.92 & Malaysia & 10 & 0.33 \\
\hline Benin & 596 & 54.79 & Indonesia & -442 & -1.71 \\
\hline Gambia & 98 & 49.35 & & & \\
\hline
\end{tabular}

Source: World Development Indicators 2015

In Table 4, we show the debt service burden on OIC countries in terms of how much of their GNI is paid as interest payments on external debt. We notice that countries with high incidence of poverty like Gabon and Mozambique pay as much as $1.5 \%$ and $1.4 \%$ of their GNI in interest payments alone on their external debt. Out of 46 countries listed in Table 4, there are 16 OIC countries 
whose interest payments alone exceed $1 \%$ of GNI. If these countries receive interest free loans or loans at concessional terms, their debt service burden can be significantly reduced and the savings can be used for funding development projects. On the other hand, we notice from Table 3 that there are at least 15 OIC countries which receive net ODA lower than $1 \%$ of their GNI. This suggests that in some OIC countries, the net outflow of resources in the form of interest payments would be greater than inflows received in the form of development assistance. Specifically, we discover that in at least 9 countries, the interest payments as a percent of GNI exceed net ODA received as a percent of GNI. These 9 countries include Kazakhstan (-2.08), Lebanon (-1.48), Indonesia (-1.27), Turkey (-1.11), Malaysia (-1.0), Gabon (-0.71), Tunisia ($0.42)$, Guyana (-0.13) and Algeria (-0.01). The numbers in parentheses indicate the difference between the net ODA received as a percent of GNI and the interest payments on the external debt as a percent of GNI.

Table 4. Interest Payment on External Debt (\% of GNI) for Selected OIC Countries

\begin{tabular}{|l|l|l|r|}
\hline \multicolumn{1}{|c|}{ Country } & $\begin{array}{c}\text { Interest on External } \\
\text { Debt }(\% \text { of GNI) }\end{array}$ & \multicolumn{1}{c|}{ Country } & $\begin{array}{c}\text { Interest on External } \\
\text { Debt } \text { \% of GNI) }\end{array}$ \\
\hline Lebanon & 3.580 & Maldives & 0.431 \\
\hline Kazakhstan & 2.132 & Pakistan & 0.428 \\
\hline Bosnia & 1.657 & Azerbaijan & 0.363 \\
\hline Tunisia & 1.556 & Benin & 0.288 \\
\hline Gabon & 1.448 & Niger & 0.286 \\
\hline Turkey & 1.408 & Egypt & 0.272 \\
\hline Mozambique & 1.366 & Mali & 0.262 \\
\hline Tajikistan & 1.343 & Yemen & 0.219 \\
\hline Jordan & 1.333 & Burkina Faso & 0.202 \\
\hline Indonesia & 1.266 & Guinea & 0.186 \\
\hline Mauritania & 1.224 & Sierra Leone & 0.186 \\
\hline Kyrgyz Republic & 1.217 & Bangladesh & 0.162 \\
\hline Senegal & 1.108 & Uganda & 0.161 \\
\hline Morocco & 1.107 & Sudan & 0.124 \\
\hline Guyana & 1.107 & Guinea-Bissau & 0.103 \\
\hline Malaysia & 1.032 & Chad & 0.087 \\
\hline Cote d'Ivoire & 0.989 & Nigeria & 0.079 \\
\hline Kosovo & 0.981 & Algeria & 0.067 \\
\hline Albania & Afghanistan & 0.050 \\
\hline Gambia & 0.673 & Comoros & 0.021 \\
\hline Cameroon & Iran & 0.020 \\
\hline Togo & 0.547 & Turkmenistan & 0.017 \\
\hline Uzbekistan & Somalia & 0.001 \\
\hline Soure: & 0.456 & & \\
\hline
\end{tabular}

Source: World Development Indicators 2015

In an Islamic economy, the wealth redistribution through Zakāt and inheritance laws ensures circulation of wealth. Aaron (1992) argues that if wealth confers economic, social and political power and hinders social mobility, then taxing wealth can reduce wealth concentration. On the other hand, 
prohibition of interest closes the door for riskless non-labor income on money capital. This increases the cost of leisure and encourages the person to supply more labor and/or invest money capital in the productive enterprise.

Islam removes the extractive institutions that perpetuate income and wealth inequality in an economy, especially the institution of interest and freedom to devise tax policy for the elite interest groups in capitalistic democracies that put the welfare of future generations in jeopardy by excessive deficit financing and inflation tax. In this sense, the Islamic approach to redistribution is both Millian and Ricardian at the same time. Islam's worldview with belief in afterlife accountability and the concept of property rights held as trust ensure that the behavior of economic agents incorporates ethical and equity concerns in their economic choices. By removing extractive institutions like interest on money capital, the income creation process is directly influenced. Then, the income created from the productive enterprise is itself redistributed as flows in the economy by taxing the stock of wealth.

Adam Smith in his monumental work "An inquiry into the nature and causes of the wealth of nations" discusses the cannons of taxation. The Zakāt based taxation system goes very well with Adam Smith's canons of taxation. It has a proportional tax and it does not tax production heavily. It is also simple and certain. It is convenient to collect and more so, because it is a religious obligation than just an involuntary tool for fetching wealth. It only taxes those who have the ability to pay i.e. it does not tax those who do not reach a minimum threshold of wealth in their hands. It can be appreciated from the classification of rates on production value tax that there is least Zakāt on the value of production which intensively uses inputs and most Zakat when the production comes from the negligible use of inputs (Siddiqui, 1982).

On the macroeconomic front, the proportional Zakāt linked with income acts as an automatic stabilizer (Yusoff, 2010). When aggregate personal disposable income increases in economic booms, more Zakät is collected and more amount is available to the government for increasing transfer payments to Fuqarah (poor and needy), Masakeen (extremely poor and needy) and Gharimeen (borrowers in trouble). When aggregate personal disposable income decreases in recessions, obligatory Zakāt also decreases and thereby providing an automatic relief to the income earners when the incomes decline.

Besides the proportional income levy, Zakāt on wealth redistributes wealth and reduces wealth concentration. So, if an economy is in disequilibrium and policies fail to immediately recover and boost incomes, wealth Zakāt enables the distributive allocation that works independently of the business cycles and helps in stabilizing the extremes of the business cycles. In this way, wealth Zakāt acts as a permanent stabilizer.

When the personal disposable incomes decline in recessions, more people will become eligible for Zakāt. Since Zakât is levied on both income and wealth, the redistribution of wealth will always be functional and operative in an Islamic economy due to wealth Zakât. Transfer payments to the unemployed, poor, needy and debtors will continue even when the economy faces a recession.

Besides this, a consistent and credible low tax rate policy with broader Zakāt base will help to minimize distortions, boost aggregate demand, encourage investment by decreasing costs of doing business and this could also simultaneously solve the microeconomic problems of imperfection in markets by increasing competition and reducing market power. 
A uniform Zakāt levy on wealth and produce can result in tax rate smoothing, stabilization of business cycle and encourage long-term investments and decision making without leaving the long-term planner in the private sector to worry about fiscal policy reversals (i.e. Ricardian equivalence).

One possible question may arise here as to how such lenient tax rates would increase substantial public revenue. The answer to this is given by the Laffer curve. Laffer (2004), a supplyside economist, himself noted that Muslim philosopher Ibn-e-Khaldun wrote about it in "The Muqaddimah". Higher tax rates discourage entrepreneurship as they decrease the incentive to produce. Lower tax rates encourage entrepreneurship and hence increase the size of the production sector and hence production. With the increase in production, tax revenue in amount increases because of a larger base. Hence, lower tax rates can still ensure high tax to GDP ratio.

Zakāt is an important tool for redistributing income and it can also increase aggregate spending. Metwally (1983) argues that Zakāt has a wider base and it is applicable to both the incomes and wealth. He emphasizes that the Zakät system has an inbuilt mechanism to reach the right targets in terms of Zakāt collection and disbursement. This ensures increasing the propensity to consume more emphatically and quickly.

Ahmad (1987) shows in a Keynesian model of the aggregate economy that expenditure multiplier in the presence of Zakāt and Infaq (charity) institutions will be higher than in a capitalist economy. Since Zakāt redistributes income from rich to the poor with direct incidence, the higher MPC for poor can also increase aggregate spending. Carroll and Kimball (1996) argue that when the income uncertainty is introduced in the standardized optimization problem, the consumption function becomes concave. Keynes (1935, p. 31) notes that the MPC is weaker in a wealthy community and as the wealth increases, the MPC starts to diminish. Empirical studies such as Souleles (1995) and Lusardi (1992) also find similar results and conclude that the MPC is considerably higher for consumers with low wealth or low income as compared to consumers with high wealth or high income. Murugasu et al. (2013) in a study in Malaysia find that MPC for lower income groups is higher than MPC for higher income households. Jappelli and Pistaferri (2014) provide empirical evidence from Italy which shows that households with low cash-onhand exhibit a much higher MPC than affluent households. Hence, the redistribution from people with lower MPC to people with higher MPC will boost aggregate spending even with the same level of income as shown before with a simple numerical simulation above.

Lastly, there will be downward pressure on the prices of durable goods with a wealth tax on tradable inventory while allowing an exemption on assets in use. For instance, if a furniture, consumer appliance or residential facility is unsold at year-end, the seller will have to pay Zakât on it. But, if the asset is sold to the buyer before the due date of Zakāt, then the subsequent owner while using such assets personally will not have to pay Zakät on these assets. This will help in checking inflation, clearing markets and promoting efficient production processes to reduce inventory cost including a physical and fiscal levy on unsold inventory at year-end. However, to avoid Zakāt arbitrage, the government has to randomly assign Zakāt due date for different retailers. It can also enact a policy to levy wealth Zakāt on tradable inventory as an average of ending and beginning inventory to counter Zakāt arbitrage. 
Institutionalizing Zakāt in Contemporary Economy

In this section, we outline recommendations at the policy and implementation level so that the institution of Zakāt can be effectively utilized to contribute in poverty alleviation.

* It is necessary that the poor people are provided with Zakāt as transfer payment for a necessary number of periods so that they can survive as well as permanently move to the status of non-poor. In this regard, the public sector educational and health institutions need to provide effective and affordable services with state of the art quality so that the income earning capacity of these poor people can be enhanced along with ensuring their survival and meeting the basic physiological needs of life.

* It is highly important that the scale and efficiency of public sector institutions in health and education are improved and poor people are provided with education, vocational training, and basic health facilities at affordable cost. In this regard, the institution of Waqf (charitable trust) can also be very effective in helping the government to increase its scale of welfare programs and outreach. Social mobility rests on effective income and capacity enhancing support programs rather than just on direct cash transfers.

* The close interaction between the Zakāt disbursement agency and the Islamic microfinance institutions is also vital. Microfinance institutions can help in identifying targets that require immediate help in meeting consumption expenditure requirements.

* For effective organization and with the objective of maximizing the benefits of Zakāt, it is appropriate to disburse Zakāt at the federal level. This way the regional disparities can be reduced more effectively.

* To gain the trust and confidence of people, it is vital to improve governance and transparency. Collection and disbursement details shall be reported in a standard way periodically.

* Creating synergies between Zakāt and other welfare programs is vital. Sufficient collection of Zakāt for filling the poverty gap is not enough to end poverty. It is important that Zakāt funds be disbursed to the right people and through right channels. It is also important to utilize the existing welfare programs for Zakāt disbursement so that the right targets can be reached more efficiently.

* It is important to modify the accounting standards to achieve transparent computation, assessment and collection.

* It is vital to improve the capacity of the public sector officials to scrutinize accounts for transparent and efficient Zakāt assessment.

* Pooling resources by transferring surplus Zakāt funds from the rich countries to the poor countries with lower wealth bases will help in alleviating poverty quickly across the Muslim majority countries (Shirazi \& Amin, 2009).

* The timing for wealth Zakāt is especially important. It is better to have an equal number of people paying Zakāt every quarter rather than all paying at a single time of the year. This will help in reducing any possible arbitrage and enable the government to 
have Zakāt funds available at all times of the year.

* In direct transfers, it is vital to give enough Zakāt per person so that the person can come out of poverty and the objective of social mobility can be achieved (Mahmud \& Haneef, 2012).

* While there is Zakāt on assets in personal use, the government in consultation with Islamic scholars has to legislate what comprises the regular and ordinary cost of living per person for different income groups. While the government shall not intervene in restraining consumption; at the same time, it shall also not allow people to avoid Zakāt by maintaining an extra ordinary living standard.

* Using same legal and administrative infrastructure established for the collection and disbursement of Zakāt, the government can invite more voluntary charitable giving besides Zakāt from domestic and overseas residents so that the scale and effectiveness of redistribution and welfare programs can be enhanced.

\section{REFERENCES}

Aaron, H. J., \& Munnell, A. H. (1992). "Reassessing the Role for Wealth Transfer Taxes", National Tax Journal, 45(2), 119 - 143.

Abdelmawla, M. A. (2014). "The Impacts of Zakāt and Knowledge on Poverty Alleviation in Sudan: An Empirical Investigation (19902009)", Journal of Economic Cooperation and Development, 35(4), $61-84$.

Abdullah, M., \& Suhaib, A. Q. (2011). "The Impact of Zakāt on Social life of Muslim Society", Pakistan
Journal of Islamic Research, 8, $85-91$.

Abu Bakar, Nur B. \& A. Rahman, A. Rahim (2007). “A Comparative Study of Zakāt and Modern Taxation", Journal of King Abdul Aziz University: Islamic Economics, 20(1), 25-40.

Ahmad, A. (1987). "Income Determination in an Islamic Economy", Jeddah: Scientific Publishing Centre, King Abdul Aziz University.

Azam, M.; Iqbal, N. \& Tayyab, M. (2014). "Zakāt and Economic Development: Micro and Macro Level Evidence from Pakistan", Bulletin of Business and Economics, 3(2), 85 - 95.

Carroll, C. D. \& Kimball, M. S. (1996). "On the Concavity of the Consumption Function", Econometrica, 64(4), 981 - 992.

Debnath, S. C.; Islam, M. T. \& Mahmud, K. T. (2013). "The Potential of Zakāt Scheme as an Alternative of Microcredit to Alleviate Poverty in Bangladesh", $9^{\text {th }}$ International Conference on Islamic Economics and Finance, QFIS, Doha, Qatar.

Food and Agriculture Organization of the United Nations (2013). "Part 3: Feeding the World" in FAO Statistical Yearbook 2013, pp. 173 - 181. FAO, Rome.

Mahmud, M. W., \& Haneef, S. S. S. (2012). "Issues in Contemporary Zakāt: A Juristic Analytical Evaluation", Kuala Lumpur: IIUM Press.

Hartman, D. A. (2002). "Does Progressive Taxation Redistribute Income", The Road Map to Tax Reform Series, Policy Report 162.

Hassan, M. K., \& Khan, J. M. (2007). "Zakāt, External Debt and Poverty Reduction Strategy in Bangladesh", Journal of 
Economic Cooperation, 28(4), 1 -38 .

Hassan, M. K. (2010). “An Integrated Poverty Alleviation Model Combining Zakāt, Awqaf and Microfinance", in Seventh International Conference-The Tawhidi Epistemology: Zakāt and Waqf Economy, Bangi, Malaysia.

Ibrahim, P. (2006). "Economic Role of Zakāt in Reducing Income Inequality and Poverty in Selangor", $\mathrm{PhD}$ Thesis, Universiti Putra Malaysia.

Jappelli, T., \& Pistaferri, L. (2014). "Fiscal policy and MPC heterogeneity", American Economic Journal:

Macroeconomics, 6(4), pp. 107 136.

Keynes, J. M. (1935). "The General Theory of Employment, Interest, and Money". San Diego, New York, London: Harvest/HBJ, 1964.

Khan, M. A. (2005). "Comments on A. Azim Islahi \& M. Obaidullah: Zakāt on Stocks: Some Unsettled Issues", Journal of King Abdul Aziz University: Islamic Economics, 18(1), 41-42.

Kuran, T. (2003). "Islamic Redistribution through Zakāt: Historical Record and Modern Realities, "in Bonner, M, Ener, M, and Singer A. (eds.). Poverty and Charity in Middle Eastern Contexts, SUNY Press, 275 - 293.

Laffer, A. B. (2004). "The Laffer Curve: Past, Present, and Future". Heritage Foundation Backgrounder, 1765.

Lusardi, A. (1992). "Permanent Income, Current Income, and Consumption: Evidence from Panel Data", Manuscript, Dartmouth College.

M. Akram, Mian \& Afzal, M. (2014). "Dynamic Role of Zakāt in
Alleviating Poverty: A Case Study of Pakistan", University Library of Munich, Germany.

Malik, S. J; Hussain, M. \& Shirazi, N. S. (1994). "Role of Infaq in Poverty Alleviation in Pakistan", The Pakistan Development Review, 33(4), $935-952$.

Metwally, M. M. (1983). "Fiscal Policy \& Resource Allocation in Islam", Islamabad: Institute of Policy Studies.

Murugasu, D., Ang, J. W., \& Tng, B. H. (2013). "Marginal Propensity to Consume Across Household Income Groups", Bank Negara Malaysia, Working Paper No.WP2/2013.

Nadvi, S. M. (1996). "Taareekh-e-Islam [History of Islam]". Lahore: Maktaba-e-Rehmania. Nadzri, F. A.; A. Rahman, R. \& Omar, N. (2012). "Zakāt and Poverty Alleviation: Roles of

Zakāt Institutions in Malaysia”, International Journal of Arts and Commerce, 1(7), $61-72$.

Naveed, A. \& Ali, N. (2012), "Clustered Deprivation - District Profile of Poverty in Pakistan", SDPI.

Norazlina A. Wahab \& A. Rahim, A. Rahman (2011). "A Framework to Analyse the Efficiency and Governance of Zakāt Institutions", Journal of Islamic Accounting and Business Research, 2(1), pp. 43 62.

Oxfam (2017). "Oxfam Briefing Paper: An Economy for the 99\%", Oxfam GB, Oxford.

Powell, R. (2009). "Zakāt: Drawing Insights for Legal Theory and Economic Policy from Islamic Jurisprudence", Pittsburgh Tax Review, 7(43), 10 - 17.

Qaradawi, Y. (1999). "Fiqh az-Zakāt: A Comparative Study-The Rules, Regulations and Philosophy of Zakāt in the Light of the Qur'an and Sunnah", Dar Al Taqwa Ltd: 
London.

Rahman, A. R. A. (2003). "Zakāt on business wealth in Malaysia: Corporate Tax Rebate, Accountability, and Governance", Journal IKIM, 11(1), 37 - 50.

Sadeq, A. H. M. (1996). "EthicoEconomic Institution of Zakāt: An Instrument of Self Reliance and Sustainable Grassroots Development", IIUM Journal of Economics and Management, 12(2), 47-69.

Shirazi, N. S. (2014). "Integrating Zakāt and Waqf into the Poverty Reduction Strategy of the IDB Member Countries", Islamic Economic Studies, 22(1), 79 108.

Shirazi, N. S. \& Amin, M. F. (2009). "Poverty Elimination through Potential Zakāt Collection in the OIC-member Countries: Revisited", The Pakistan Development Review, 48(4), 739 754.

Siddiqui, S. A. (1982). "Public Finance in Islam". New Delhi: Adnan Publishers \& Distributors. Souleles, N. S. (1995). "The Response of Household Consumption to Income Tax Refunds", Manuscript, the Massachusetts Institute of Technology.

Suprayitno, E., Kader, R. A., \& Harun, A. (2013). "The Impact of Zakāt on Aggregate Consumption in Malaysia", Journal of Islamic Economics, Banking and Finance, 9(1), $39-62$.

Wahid, A. N. M. (1986). "The Economic Implications of Zakāt", Contemporary Review, 248 (1440), p. 10.

Wahid, H., Ahmad, S. \& Kader, A. R. (2008). "Distribution of Zakāt in Malaysia: Why are the Muslims Still Dissatisfied", Proceedings of Seminar Kebangsaan Ekonomi
Malaysia, Universiti Kebangsaan Malaysia, Bangi.

Yusoff, M. B. (2011). "Zakāt Expenditure, School Enrollment, and Economic Growth in Malaysia", International Journal of Business and Social Science, 2(6), $175-181$.

Yusoff, M. B. (2010). "An Analysis of Zakāt Expenditure and Real Output: Theory and Evidence", Management and Accounting, 18(2), $139-160$.

Salman Ahmed Shaikh

SZABIST Karachi

Pakistan

salman@siswa.ukm.edu.my 
